\title{
ISSUES RELATED TO THE ADHESION BETWEEN DEFORMED REINFORCEMENT AND CONCRETE
}

\author{
Anatoly Veselov ${ }^{1}$, Aleksandr Chernykh ${ }^{2}$, Aleksandr Maslennikov ${ }^{3}$, Vyacheslav Kharlab ${ }^{4}$, Shirali Mamedov ${ }^{5}$ \\ 1,2,3,4,5Saint Petersburg State University of Architecture and Civil Engineering \\ Vtoraja Krasnoarmeyskaya st., 4, Saint Petersburg, Russia
}

2Corresponding author: ag1825831@mail.ru

\begin{abstract}
Introduction: Based on an analysis of issues related to the anchorage and active adhesion between deformed reinforcement and concrete, it is possible to identify major problems of concrete-to-steel bond breaking during the operation of bearing building structures. Purpose of the study: The authors seek to determine the mechanism of interaction between concrete and steel in the adhesion contact area, establish a relationship between external force action and crack development in the contact area. Methods: The authors suggest some dependencies to evaluate various test methods when determining the area where two materials, differing in physical characteristics, interact. Approximation to the actual phenomena related to the interaction between concrete and reinforcement, starting from the moment when through and non-through internal cracks form in the contact area and ending with destruction, is a general problem of models describing the adhesion of materials. Results: The theoretical results were compared with the experimental data and recommendations of modern regulatory documents, and it was found that they are in a satisfactory agreement. It was established that the difference of axial deformations of the bar and the surrounding concrete goes into the difference of bending displacements, which explains uneven load distribution across the protrusions. Discussion: Using the suggested dependencies, it is possible to predict crack development in the contact area of the reinforcement and cement binder as well as in the slip area in an extreme case. The concrete tensile strength in particular reinforcedconcrete elements in supporting cross-sections and with anchorage in tensile concrete represents a factor affecting the strength of the concrete-to-steel bond.
\end{abstract}

\section{Keywords}

Anchorage, reinforcement adhesion, concrete.

\section{INTRODUCTION}

According to the results of studying the concrete-tosteel bond, no sufficiently reliable theories have been developed yet, where the relationship between shear stresses and displacements would be based on contact problems. Such problems are solved using additional assumptions, including numerical methods. Some researchers (Karpenko and Gorshenina, 2006; Karpenko and Karpenko, 2001; Prokopovich, 2000; Savrasov, 2009; Sechenkov et al., 2007; Zikeev and Tsyba, 2009) modeled the mechanical interaction of materials in the active concrete-to steel bond area. This area is represented by conical shells. In this case, the effect of moments, normal and transverse forces, as well as circumferential cracks, is taken into account (Karpenko and Karpenko, 2001). The obtained resolving equations are represented in finite differences. Solving a system of equations of the $26^{\text {th }}$ order, it is possible to determine reinforcement displacements relative to concrete. One of the traditional tests performed when studying the adhesion of materials is a pull-out test, i.e. pulling reinforcement bars out of a concrete prism (cylinder) supported at its end face. Besides, reinforcement anchorage in tensile concrete has received almost no attention from researchers.

An analysis of studies related to the concrete-tosteel bond reveals a mixed approach to the solution (Kashevarova et al., 2016), a lack of a uniform and theoretically substantiated method of calculation (including under non-linear conditions): there is no unified approach to the solution of a problem in obtaining an equation for the compatibility of deformations for various types of force application along the length of the contact area of materials; the stress state of concrete and reinforcement in the contact area (both in the presence and in the absence of circumferential non-through cracks) has not been studied sufficiently; there is no clarity regarding the solution of a problem related to the adhesion of materials and their relative displacement at the elastoplastic stage of linear and non-linear concrete creep; materials of the adhesion theory are not sufficiently widely used in practical methods of designing reinforced-concrete structures and analyzing their sections. 


\section{BACKGROUND}

Approximation to the actual phenomena related to the interaction between concrete and reinforcement, starting from the moment when through and non-through internal cracks form in the contact area and ending with destruction, is a general problem of the considered models describing the adhesion of materials.

A bond between deformed reinforcement and concrete was taken as a design model (Veselov, 2000) according to the scheme shown in Figure 1. A short sample is pulled out by forces applied to the concrete-free end of the bar embedded in concrete on the one side, and concrete on the other side. The forces are as follows: N3 $=\mathrm{N}, \mathrm{N} 4=0$.

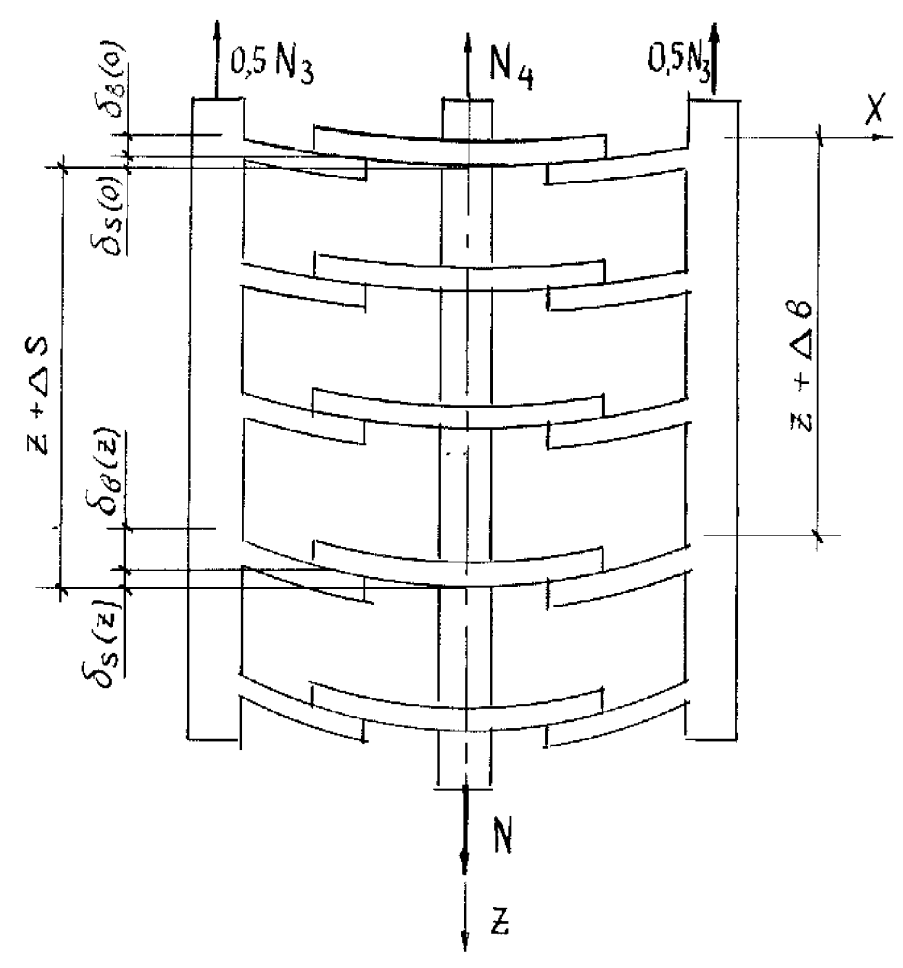

Figure 1

Concrete-to-steel bond design model

We suppose that inelastic deformations develop in concrete protrusions and that reinforcement protrusions in the contact area are characterized by elastic behavior. Let us accept the following assumptions:

1. In areas of force application from rebars to concrete, the bond is tight.

2. Contacts before and after deformations are observed for all protrusions (Veselov, 2012; Veselov and Chepilko, 2010; Veselov and Pukharenko, 2015).

3. The concrete-to-steel bond is considered as a bond with continuous protrusions.

\section{METHODS}

The authors analyze reinforcement anchorage that is most frequently used in reinforced-concrete structures - pulled out of tensile concrete of a certain area. In this case, tensile forces appear in the contact area as well as the reinforcement. A case when internal circumferential cracks form in the contact area is considered.

\section{CASE HISTORY}

Adhesion between reinforcement and concrete can be estimated by the value of shear adhesion acting along the conventional cylindrical surface of the contact area (Veselov, 2000). The convention is in the fact that, even in case of plain reinforcement bars, materials contact along the surface having various protrusions and irregularities. As for plain reinforcement bars, shear adhesion of materials is mainly provided by bonding between the cement gel and reinforcement as well as lateral friction. According to numerous researchers (Choi and Lee, 2002; Choi and Yang, 2010; Karpenko, 2001; Kashevarova et al., 2016, Plevkov et al., 2016), mechanical interlocking due to transverse protrusions on the lateral surface is an essential aspect in adhesion when it comes to deformed reinforcement.

Kashevarova and her colleagues described factors affecting the concrete-to-steel bond strength (Kashevarova et al., 2016). The laws of interaction between concrete and reinforcement determine the specifics of reinforced concrete as a material. The concrete-to-steel bond strength depends on the state of the metal surface, concrete adhesion and cohesion, concrete hardening conditions and age, degree of reinforcement compression during shrinkage, and type of the stress state in the contact area. During loading, the stress state is continuously complicated due to the appearance and development of new transverse and longitudinal cracks breaking the contact between the reinforcement and concrete. Adhesion is conditioned by molecular bonding forces between the surfaces of two dissimilar or liquid contacting bodies. During concrete laying, favorable conditions are created for the manifestation of adhesion in the area of contact with rigid reinforcement.

Concrete plasticity can be increased in the course of vibration compaction. As a result, concrete approaches the metal surface and continuity of contact between them increases. It is known that non-treated steel is wettable and has a tight adhesion with concrete. However, adhesion between concrete and polished steel slightly decreases as continuity of contact at the interface of concrete and treated surfaces is quite high.

\section{RESULTS}

In case of the adopted design model of material interaction and taken assumptions, under the action of the force $\mathrm{N}$, the reinforcement bar at some section of length $\mathrm{z}$ will elongate by $\Delta B$, and the body of the concrete prism at this section will elongate by $\Delta c$. Under external loading, reinforcement bar and concrete protrusions will be subject to bending deformations. Let us denote rebar protrusion deflection in the section $z$ relative to its base by $\delta_{b}(z)$, and concrete protrusion deflection - by $\delta_{c}^{\prime}(z)$. 
Based on the taken assumptions and adhesion geometry (Karpenko and Gorshenina, 2006), the condition for the compatibility of deformations can be written as follows:

$$
\Delta B-\Delta c=\left[\delta_{b}(z)+\delta_{c}^{\prime}(z)\right]-\left[\delta_{b}(0)+\delta_{c}^{\prime}(0)\right]
$$

where $\delta_{b}(z)+\delta_{c}^{\prime}(z)$ is the sum of reinforcement and concrete protrusions' displacements in the section at a distance $\mathrm{z} ; \delta_{b}(0)+\delta_{c}^{\prime}(0)$ is the same but in the section $\mathrm{z}=0$.

It follows from equation (1) that the difference of axial deformations of the bar and the surrounding concrete goes into the difference of bending displacements, which explains uneven load distribution across the protrusions. When deriving dependency (1), the bond model is not significant. Therefore, equation (1) remains valid for other outlines of deformed reinforcement as well (not only for helical).

Let us assume that stresses $\sigma_{b}$ and $\sigma_{c}$ uniformly distributed across the cross-section act in the bar and surrounding concrete at some distance from the reinforcement surface. Linear displacements in equation (1) can be expressed by force factors:

$$
\Delta B=\int_{0}^{z} \frac{\sigma_{b}}{E_{b}} d z ; \Delta c=\int_{0}^{z} \frac{\sigma_{c}}{E_{c}{ }^{\prime}} d z
$$

where $E_{b}$ and $E_{c}^{\prime}$ are reinforcement elasticity modulus and concrete deformation modulus, respectively.

Let us assume that dependency (1) is valid not for any point of the lateral surface regarding protrusions and their outlines, but for points $\mathrm{M}, \mathrm{Ob}, \mathrm{Oc}$.

Taking the pressure along the protrusions as uniformly distributed and their deformations as isolated from each other, and considering the taken assumptions, linear displacements can be represented by the following equations:

$$
\delta_{b}(z)=\frac{p(z) S_{b}}{E_{b, v}} \lambda_{b(z)} ; \delta_{b}^{\prime}(z)=\frac{p(z) S_{c 1}}{E_{c, v}^{\prime}} \lambda_{c(z)}
$$

where $S_{c}$ and $S_{c l}$ - the height of the concrete and rebar protrusions in the contact area; in the absence of circumferential cracks in concrete in the contact area, $S_{c}=S_{c l}$, where $S_{c l}$ - the spacing between the rebar protrusions. $\lambda_{C(z)}$ and $\lambda_{C(z)}$ - dimensionless coefficients that depend on the geometry of the reinforcement, presence or absence of cracks in the contact layer of concrete surrounding the bar, possible defects of concrete protrusions, etc.

Taking into account equations (2) and (3), basic equation (1) can be written as follows:

$$
\int_{0}^{z} \frac{\sigma_{b}}{E_{b}} d z-\int_{0}^{z} \frac{\sigma_{c}}{E_{c}^{\prime}} d z=[p(z)-p(0)] \times\left[\frac{S_{b}}{E_{b, v}} \lambda_{b}(z)+\frac{S_{c 1}}{E_{c, v}} \lambda_{c}(z)\right.
$$

Let us set boundary conditions at the end faces of the element for the adopted design model:

$$
\begin{array}{lll}
\mathrm{z}=\text { lan } & \mathrm{Nb}=\mathrm{N} ; & \mathrm{Nc}=0 \\
\mathrm{z}=0 & \mathrm{Nc}=\mathrm{N} ; & \mathrm{Nb}=0 .
\end{array}
$$

Then, taking into account (5) in the section z, forces in the reinforcement and concrete, respectively, will be as follows:

$$
N_{b}(z)=\int_{0}^{z} q_{b 1}(z) d z ; N_{c}(z)=N-N_{b}(z)=N-\int_{0}^{z} q_{b 1}(z) d z
$$

Let us establish a relationship between pressure $\mathrm{p}(\mathrm{z}), q_{b 1}(z)$, and $q_{c 1}(z)$. Based on the following equations:

$$
\begin{aligned}
& d N_{b}(z)=p(z) d f=q_{b 1}(z) d z \\
& \text { and } \\
& d N_{c}(z)=p(z) d f=q_{c 1}(z) d z \\
& \text { we obtain } p(z)=q_{b 1}(z) \frac{S_{c 1}}{f} \text { and } p(z)=q_{c 1}(z) \frac{S_{c 1}}{f}
\end{aligned}
$$

where $f=\left(\pi d_{b}-2 b\right) t_{1}$ - the projection of the lateral surface of the protrusion on a plane perpendicular to the $z$ axis; $d_{b}$ - the average diameter of the protrusions, $d_{b}=0.5(d+d 1)$ (Karpenko and Gorshenina, 2006) 11 - the effective depth of a protrusion; $b$ - the width of the longitudinal edge. 
Substituting initial data from equation (6) with account for equation (7) in equation (4), we obtain the following:

$$
\begin{aligned}
& \int_{0}^{z} \beta_{1}(z)\left[\int_{0}^{z} q_{b 1}(z)\right] d z-\int_{0}^{z} \frac{N}{E_{c}^{\prime} A_{c}} d z=q_{1}(z) \gamma_{1}(z)-q_{b 1}(0) \gamma_{1}(0) \\
& \text { At } \quad z=l_{a n}, \quad q_{b 1}(0)=\frac{1}{\gamma_{1}(0)}\left[q_{b 1}\left(l_{a n}\right) \gamma_{1}\left(l_{a n}\right)-\int_{0}^{l_{a n}} \frac{N}{E_{b} A_{b}} d z\right]
\end{aligned}
$$

Transforming equation (9) and taking into account equation (8) we obtain the following:

$$
q_{b 1}(z)=\frac{1}{\gamma_{1}(z)}\left[\int_{0}^{z} \beta_{1}(z) \int_{0}^{z} q_{b 1}(z) d z d z-\int_{0}^{z} \frac{N}{E_{c}^{\prime} A_{c}} d z+q_{b 1}\left(l_{a n}\right) \gamma_{1}\left(l_{a n}\right)+\frac{N}{E_{b}^{\prime} A_{b}} l_{a n}\right]
$$

Equation (10) makes it possible to obtain the intensity of forces distribution along the length of a reinforcement bar, considering the inelastic behavior of concrete in the contact area and beyond. Let us define the line force in the element under consideration with account for the elastic behavior of materials. To this end, we accept the following:

$$
\gamma_{1}(z)=\gamma=\mathrm{const} ; \quad \beta_{1}(z)=\beta=\mathrm{const}^{\circ}
$$

Having differentiated equation (10) with respect to $z$ and taking $q_{b 1}(z)=q_{b}(z)$, we obtain:

$$
\gamma q^{\prime}(z)-\beta \int_{0}^{z} q_{b}(z) d z+\frac{N}{E_{c} A_{c}}=0
$$

Then we differentiate dependency (11) with respect to z:

$$
q_{b}^{\prime \prime}(z)-m^{2} q_{b}(z)=0 .
$$

where $m^{2}=\beta / \gamma$, or $m=\sqrt{\beta / \gamma}$ is an adhesion characteristic, which in the general case can be represented as follows:

$$
m=\sqrt{\beta / \gamma}=\sqrt{\frac{\left(1+\frac{E_{b} A_{b}}{E_{c}^{\prime} A_{c}}\right) f}{E_{b} A_{b} \cdot S_{c 1} S_{b}\left(\frac{\lambda_{b(z)}}{E_{b, v}}+\frac{\lambda_{c(z)}}{E_{c, v}^{\prime}} \cdot \frac{S_{c 1}}{S_{b}}\right)}}
$$

All these values are presented in detail in a paper by Veselov and Chepilko (Veselov and Chepilko, 2010). General integral (12) can be represented as follows:

$$
q_{b}(z)=A \operatorname{shm} z+B \operatorname{chm} z
$$

Having differentiated equation (13) with respect to $z$ and taking the boundary conditions at $z=0 \quad q_{b}^{\prime}=A_{m}$ :

$$
\begin{gathered}
z=\text { lan } \quad q_{b(\text { lan })}^{\prime}=A m c h m z+B m \operatorname{shm} z, \\
A=-\frac{1}{\gamma m} \cdot \frac{N}{E_{c} A_{c}} ; \quad B=\frac{N}{\gamma m s h m l_{a n}}\left(\frac{1}{E_{b} A_{b}}+\frac{c h m l_{a n}}{E_{c} A_{c}}\right) .
\end{gathered}
$$

Substituting the values of the $A$ and $B$ constants in general integral (10) and transforming the equation, we obtain the following: 


$$
q_{b}(z)=\frac{N m}{\beta \cdot s h m \cdot l_{a n}} \cdot\left(\frac{\operatorname{chm} z}{E_{b} A_{b}}+\frac{\operatorname{chm} \cdot\left(l_{a n}-z\right)}{E_{c} A_{c}}\right)
$$

\section{CONCLUSIONS}

Studying the concrete-to-steel bond, numerous authors came to the conclusion that the compression of reinforcement and concrete protrusions is the main factor in the contact area. According to other researchers, during the interaction of materials, tensile stresses occur that lead to the formation of circumferential cracks (Karpenko, 2001) in the contact area. Based on an analysis of the proposed dependencies, the following can be concluded: regardless of force application, the interaction of materials results in tensile or - when the reinforcement is pulled out of a prism supported at its end face - shear forces in concrete that depend on the concrete tensile strength. The concrete tensile strength in particular reinforced-concrete elements in supporting cross-sections and with anchorage represents a factor affecting the strength of the concrete-to-steel bond. 


\section{References}

Canbay, E. and Frosch, R.J. (2005). Bond strength of lap-spliced bars. ACI Structural Journal, 102 (4), pp. 605-614.

Choi, O.C. and Lee, W.S. (2002). Interfacial bond analysis of deformed bars to concrete. ACI Structural Journal, 99 (6), pp. 750-756.

Choi, O.C., and Yang, S.Y. (2010). Bond analysis model of deformed bars to concrete. In: Proceedings of the $7^{\text {th }}$ International Conference on Fracture Mechanics of Concrete and Concrete Structures, Jeju, Korea, May 23-28, 2010. Seoul: Korea Concrete Institute, pp. 811-815.

Karpenko, N.I. and Karpenko, S.N. (2001). Towards formation of physical relations in the incremental form for the design of reinforced-concrete structures with cracks. In: Proceedings of the $1{ }^{\text {st }}$ All-Russian Conference "Concrete at the Turn of the Third Millennium", Book 2. Moscow: Gotika, pp. 765-777.

Karpenko, N.I. and Gorshenina, Ye.V. (2006). Method of calculating the distance between cracks in reinforced-concrete members subject to bending. Beton i Zhelezobeton, 5, pp. 13-15.

Kashevarova, G.G., Martirosyan, A.S. and Travush, V.I. (2016). Computational and experimental research of the contact debonding process when rigid reinforcement is pressed into concrete. PNRPU Mechanics Bulletin, 3, pp. 62-75. DOI: 10.15593/perm. mech/2016.3.04.

Plevkov, V., Belov, V., Baldin, I., Nevskiy, A., Veselov, A. and Serov, E. (2016). Diagram of non-linear straining of carbon-fiber reinforced concrete at static effect. Material Science Forum, Vol. 871, pp. 173--81. DOI: 10.4028/www.scientific.net/MSF.871.173.

Prokopovich, A.A. (2000). Bending strength of reinforced-concrete structures with different conditions of adhesion between longitudinal reinforcement and concrete. Samara: NVF Sensory, Moduly, Sistemy, 296 p.

Savrasov, I.P. (2009). Experimental studies of mechanical properties and bond between concrete and reinforcement with a yield strength of $500 \mathrm{~N} / \mathrm{mm}^{2}$. Beton i Zhelezobeton, 4, pp. 16-21.

Semchenkov, A.S., Zalesov, A.S., Meshkov, V.Z and Kvasnikov, A.A. (2007). Nature of bond between concrete and reinforcement bars of various profiles. Beton i Zhelezobeton, 5, pp. 2-7.

Veselov, A.A. (2000). Non-linear theory of concrete-to-steel bond. DSc Thesis in Engineering. Saint Petersburg: Saint Petersburg State University of Architecture and Civil Engineering.

Veselov, A.A. and Chepilko, S.O. (2010). Stress and strain state in a steel-reinforced concrete beam. Bulletin of Civil Engineers, 2, pp. 31-37.

Veselov, A. A. (2012). Concrete and reinforcement protrusions displacement in the materials adhesion zone. Bulletin of Civil Engineers, 1, pp. 75-79.

Veselov, A., and Pukharenko, Y. (2015). Calculation on formation of longitudinal cracks in reinforced concrete structures taking into account nonlinearity of concrete straining. Applied Mechanics and Materials, Vols. 725-726, pp. 802-807. DOI: 10.4028/ www.scientific.net/AMM.725-726.802.

Zikeev, L.N. and Tsyba, O.O. (2009). Crack resistance of reinforced concrete tension elements taking into account relative square of tensile reinforcement. Industrial and Civil Engineering, 10, pp. 30-32. 


\title{
ПРОБЛЕМЫ СЦЕПЛЕНИЯ АРМАТУРЫ ПЕРИОДИЧЕСКОГО ПРОФИЛЯ С БETOHOM
}

\begin{abstract}
Анатолий Александрович Веселов ${ }^{1}$, Александр Григорьевич Черных², Александр Матвеевич Масленников ${ }^{3}$, Вячеслав Данилович Харлаб ${ }^{4}$, Ширали Махаррамович Мамедов ${ }^{5}$
\end{abstract}

1,2,3,4,5Санкт-Петербургский государственный архитектурно-строительный университет

2-ая Красноармейская ул., 4, Санкт-Петербург, Россия

²E-mail: ag1825831@mail.ru

\begin{abstract}
Аннотация
Введение. Анализ состояния вопросов анкеровки и активного сцепления арматуры периодического профиля с бетоном раскрывает основные проблемы разрушения сцепления арматуры с бетоном в процессе эксплуатации несущих строительных конструкций. Цель. Раскрытие механизма взаимодествия между бетоном и сталью в зоне адгезионного контакта, установление связей между внешним силовым воздействием и развитием трещин в зоне контакта материалов. Методы. Предлагаются зависимости для оценки различных методов испытания при определении зоны взаимодействия двух различных по фризиеским характеристикам материалов. Общей задачей моделей сцепления материалов является приближение к действительному характеру протекающих явлений взаимодействия бетона и арматуры, начиная с момента образования несковозных и сквозных внутренних трещин в месте контакта материалов вплоть до разрушения. Результаты. Проведено сравнение теоретических результатов с опытными данными и предложениями современных нормативных документов, которые удовлетворительно согласуются. Установлено, что разность осевых деформаций стержня и окружающего бетона переходит в разность изгибных перемещений, что и объясняет причину неравномерного распределения нагрузки по выступам. Обсуждение. С помощью предложенных зависимостей можно прогнозировать развитие трещин в зоне контакта арматуры и цементного связующего и проскальзывания в предельном случае. Прочность бетона на растяжение в конкретных железобетонных элементах в опорных сечениях и при анкеровке в растянутом бетоне является фактором, влияющим на прочность сцепления в контактной паре «сталь-бетон».
\end{abstract}

\section{Ключевые слова}

Анкеровка, сцепление арматуры, бетон. 